\title{
DE ZOÖLOGISCHE TUIN VAN HEDEN EN MORGEN
}

\author{
DOOR \\ Dr. A. L. J. SUNIER \\ Directeur van het Koninklijk Zoölogisch Genootschap „Natura Artis Magistra" \\ te Amsterdam
}

Wanneer een instelling honderd jaar bestaat, heeft zij, naar menschelijke opvatting, op den weg, waarlangs haar ontwikkeling loopt, een mijlpaal bereikt.

$\mathrm{Bij}$ zoo'n mijlpaal wil men gaarne een oogenblik vertoeven, om terug te blikken langs den afgelegden weg.

Men kan echter ook de omgeving van den mijlpaal, het punt, dat men bereikt heeft, wat nauwkeuriger in oogenschouw nemen, om daarna te trachten vooruit te zien en te ontdekken, waarheen de weg voert, die in de toekomst leidt.

Over de vraag, wat het doel van een zoölogischen tuin is en hoe de inrichting en werkwijze daarvan moeten zijn, bestaat op het oogenblik onder ter zake kundigen wel geen principieel verschil van meening.

De zoölogische tuin heeft niet een commercieel, doch uitsluitend een cultureel doel. Dit doel is in de eerste plaats het publiek het levende dier te leeren kennen in zijn uiterlijk, zijn gedrag en verdere levensverschijnselen alsmede in zijn schoonheid.

De levende dieren, die met dit doel in den zoölogischen tuin zijn bijeengebracht, leveren bovendien, hetzij tijdens hun leven, hetzij na hun dood, of zelfs tijdens hun leven en na hun dood, uiterst belangrijk studiemateriaal op voor biologen, die op het gebied der systematiek, faunistiek, morphologie, physiologie, psychologie enz. werkzaam zijn, alsook voor beofenaars der veterinaire wetenschappen.

Onder hen, die van de aanwezigheid van den zoölogischen tuin profiteeren, mogen verder speciaal leerlingen van inrichtingen van Lager, Middelbaar, Gymnasiaal en Vak-Onderwijs genoemd worden, die in klasseverband, onder leiding der betrokken leerkrachten, de instelling bezoeken, alsook leerlingen van inrichtingen van onderwijs, waar teekenen naar de natuur een vereischte is, zooals leerlingen van kunstnijverheid- en teekenscholen. Voorts leerlingen van kweekscholen en opleidingscursussen voor onderwijzers en onderwijzeressen, studenten in de biologie en in de veterinaire wetenschappen en last, not least beeldende kunstenaars, die onder de levende have hun studie-objecten vinden. 
Hierbij mag niet onopgemerkt blijven, dat de beteekenis van den zoölogischen tuin voortdurend toeneemt, gezien het feit, dat, in verband met verschillende omstandigheden, waaronder in de eerste plaats het zich steeds meer uitbreiden van het cultuurland, overal ter wereld de gebieden, waar grootere dieren en vooral groote zoogdieren hun bestaansmogelijkheden gerealiseerd vinden, steeds kleiner en schaarscher worden. Immers, indien het al mogelijk zal zijn het voortbestaan van zoodanige diersoorten in natuur-reservaten te verzekeren, zoo zal, op weinige bevoorrechte uitzonderingen na, de menschheid alleen in den zoölogischen tuin gelegenheid vinden, levende vertegenwoordigers van dergelijke diersoorten te leeren kennen. Men denke hierbij o.a. aan de kudde wisenten, de Komodo-waranen en den gorilla in "Artis”.

Bovendien kan daarbij, zooals in het geval der zich voortdurend door geboorte-overschot uitbreidende kudde wisenten in „Artis”, de zoölogische tuin een belangrijke rol spelen in zake het voor algeheel uitsterven behoeden van soorten, die in het wild reeds niet meer voorkomen.

In verband met het bovenstaande zal het begrijpelijk zijn, dat men in vakkringen groote waarde hecht aan een nauwen band tusschen zoölogischen tuin en universiteit. Met voldoening mag geconstateerd worden, dat, waar elders ter wereld veelal nog slechts gestreefd wordt naar het leggen van zoodanigen band, hier te Amsterdam deze band tusschen de universiteit en het Koninklijk Zoölogisch Genootschap „Natura Artis Magistra” reeds gelegd werd bij een overeenkomst van 1877 en door verschillende verdere overeenkomsten in den loop der jaren versterkt werd.

Ingevolge deze overeenkomsten werden de verzamelingen van het Genootschap dienstbaar gemaakt aan het universitaire onderwijs te Amsterdam, werd het Zoölogisch Laboratorium der Universiteit van Amsterdam in één der, in den tuin van het Genootschap gelegen gebouwen van het Genootschap gevestigd en kwam, onder samenvoeging der zoölogische museum-verzamelingen van de Gemeente Amsterdam en van het Genootschap, het eveneens in den tuin van het Genootschap gelegen en in gebouwen van het Genootschap gehuisveste „Zoölogisch Museum te Amsterdam” tot stand.

Bovendien wordt, op grond dezer overeenkomsten, door het Genootschap niet alleen aan alle hoogleeraren, conservatoren en assistenten, die werkzaam zijn op het zoölogisch museum en op het zoölogisch laboratorium, maar ook aan alle studenten, die deze inrichtingen moeten bezoeken, d.w.z. geregeld aan 200 à 300 dezer jongelieden, gratis toegang tot den tuin, de belangrijke zoölogische bibliotheek en alle verdere verzamelingen van het Genootschap verleend.

In 1928 werd voorts, op initiatief en met medewerking van Dr. J. A. Bierens de Haan, door het Genootschap in één zijner gebouwen een laboratorium voor onderzoekingen op het gebied van de psychologie der dieren ingericht, waar thans gewerkt wordt door Dr. Bierens de Haan, privaat-docent voor experimenteele zoölogie aan de Universiteit van Amsterdam en onder diens leiding door verschillende biologen, grootendeels met levende dieren, die het eigendom 
zijn van het Genootschap en die door het Genootschap ter beschikking van Dr. Bierens de Haan worden gesteld.

Uit den aard der zaak kan een zoölogische tuin dagelijks een schat van gegevens opleveren aangaande gedrag, voortplanting, geboorte en opgroeien en verdere levensverschijnselen, abnormaliteiten, ziekten en doodsoorzaak, alsmede betreffende de eischen eener rationeele voeding en verzorging der in den tuin levende dieren. In "Artis” worden sedert 1928 deze gegevens dagelijks vastgelegd in dagrapporten; stamboeken en verslagen van sectiones post mortem. Uit deze gegevens werd o.a. geput door Dr. C. J. Folmer en den Heer A. F. J. Portielje bij het schrijven hunner publicaties, die in dit feestnummer der „Bijdragen tot de Dierkunde”, de door het Genootschap sedert I848 uitgegeven zoölogische periodiek, worden aangetroffen.

Aan het bijeenbrengen dezer gegevens wordt door het geheele personeel van "Artis", dat werkzaam is bij de verzorging der dieren, medegewerkt. Alles, wat door dit personeel gedurende de afgeloopen 24 uur aangaande de dieren werd opgemerkt, wordt elken morgen verzameld door het daarvoor in aanmerking komende hoogere personeel, met den directeur besproken en in het dagrapport ingeschreven.

Daarbij worden deze gegevens tegelijkertijd volgens een eenvoudig, overzichtelijk systeem geregistreerd in de stamboeken. Hierdoor is het mogelijk onmiddellijk b.v. voor een bepaald dier alle aanteekeningen aangaande het van dit dier waargenomen gedrag te vinden, of, om een ander voorbeeld te noemen, alle gegevens aangaande ziekteverschijnselen, geconstateerd bij de in den tuin levende of geleefd hebbende vertegenwoordigers van een bepaalde diersoort, op te slaan.

Betreffende de eischen, waaraan het dierenverblijf moet beantwoorden, bestaat heden ten dage onder leeken, zoowel hier te lande als daarbuiten, veel misverstand. Dit misverstand berust op onjuiste voorstellingen, die men zich van den aard van het dier en van diens behoeften maakt. Het tot stand komen dezer onjuiste voorstellingen wordt in de hand gewerkt door de meer of minder misleidende reclame, die tegenwoordig veelal gemaakt wordt door inrichtingen, die, met commercieele bedoelingen, dieren voor het publiek ten toon stellen. Dergelijke inrichtingen zijn niet gelijkwaardig met een werkelijk zoölogischen tuin. Uit den aard der zaak bestaan er tusschen een zoölogischen tuin, waarvan het doel uitsluitend cultureel is en waarvan de leiding over natuurwetenschappelijke kennis en inzicht beschikt en een geheel op den sensatielust van het publiek ingestelde menagerie alle mogelijke overgangen.

Algemeen verbreid is de meening, dat men de dieren niet meer in ,hokken" of "kooien", „achter tralies" moet houden, doch ,in vrijheid" en dat men moet trachten het den dieren in een zoölogischen tuin, zoowel wat hun omgeving (huisvesting) als hun voeding betreft, juist zoo te geven, als zij het in de natuur hebben.

Deze meening heeft vooral ingang gevonden sedert Carl Hagenbeck in 1907 
het bekende dierenpark te Stellingen opende, waar de eerste z.g. „Frei-Anlagen", d.w.z. ruime dierenverblijven zonder tralies, hekwerk of ijzergaas, die den indruk willen geven van een natuurlijk landschap, door den Zwitser Urs Eggenschwyler gebouwd werden.

Carl Hagenbeck zelf schreef indertijd over deze verblijven: „Ich wollte den Tierliebhabern an einem grossen und dauernden Beispiel zeigen, dass es gar nicht nötig sei luxuriöse und kostspielige Gëbäude mit grossen Heizanlagen einzurichten, um die Tiere im Leben und gesund $z \mathbf{u}$ erhalten, sondern dass der Aufenthalt in freier Luft und die Gewöhnung an das Klima eine weit bessere Gewähr für die Erhaltung der Tiere bedeutet”.

Men heeft later ingezien, en ook Hagenbeck zelf heeft dit ingezien, dat deze uitspraak niet geheel juist is. Inderdaad is het voor vele dieren, waaronder ook de meeste tropische zoogdieren en vogels, gunstig, wanneer men hen zooveel mogelijk in de buitenlucht brengt. $Z_{\mathrm{ij}}$ kunnen daarbij, zonder daarvan schade te ondervinden, geregeld blootgesteld worden aan veel lagere temperaturen en meer guur weer dan men aantreft in de.streken, waarin zij in het wild leven. Zulke dieren moeten daarnaast dan echter, althans gedurende den nacht en ook wel gedurende een gedeelte van den dag, bij al te slecht weer, ondergebracht kunnen worden in voldoend ruime, hygiënische, verwarmbare en ook in alle andere opzichten op geschikte wijze ingerichte binnenverblijven. Overigens komen, juist als onder de menschen, ook onder de tot een zelfde soort behoorende dieren groote individueele verschillen voor, wat betreft gevoeligheid voor koude en guur weer. Ook voor dieren is een individueele verzorging van zeer groot belang.

Sedert de opening van het dierenpark van Hagenbeck te Stellingen werden dierenverblijven als hier bedoeld over de geheele wereld in zeer vele dierentuinen gebouwd. Op groote schaal geschiedde zulks o.a. in het Parc Zoologique du Bois de Vincennes, dat een afdeeling vormt van het Muséum National d'Histoire Naturelle te Parijs.

In een, ter gelegenheid der opening, op den 2den Juni 1934, van dit Parc Zoologique, in de "Illustration” verschenen artikel kan men lezen: „Dissimuler les clôtures, créer des locaux bien aérés et salubres, donner l'illusion du paysage sauvage, tels étaient les éléments du problème qui avait été posé".

Inderdaad ligt de overigens groote beteekenis der hier bedoelde, in het Duitsch „Frei-Anlagen” genoemde dierenverblijven practisch gesproken alleen daarin, dat zij den menschelijken toeschouwer de illusie geven van een natuurlijk landschap, waarin hij de dieren ziet rondloopen of liggen. Tegenover oudere dierenverblijven bieden $z \mathrm{ij}$, principieel, geen bijzondere voordeelen met het oog op een zoo rationeel mogelijke verzorging der dieren. Men heeft $\mathrm{nl}$. reeds sedert geruimen tijd ingezien, dat men in de eerste plaats in alle opzichten voortreffelijke, ruime, goed ventileer- en verwarmbare, hygiënische dierenverblijven moet bouwen, waarin elk dier afzonderlijk in een aparte ruimte ondergebracht en individueel verzorgd kan worden. Daarna kan men dan deze 
verblijven aan het oog van den toeschouwer onttrekken, door er omheen kunstmatige rotspartijen te bouwen met weer daarbuiten vlakkere terreinen, waar de dieren buiten kunnen loopen en die, via gecamoufleerde doorgangen, door de rotspartijen heen, met de binnenverblijven in verbinding staan, terwijl zij aan den anderen kant, b.v. door een voldoend breede, al dan niet met water gevulde gracht van het publiek gescheiden zijn.

Uit den aard der zaak tracht men steeds in deze kunstmatige landschappen, die als buitenverblijf voor de dieren dienen, een grooter aantal tot één en dezelfde soort, of ook wel tot verschillende soorten behoorende dieren bijeen te brengen. Dit geldt ook voor een tweede, nieuwste type dierenverblijf, gerealiseerd in het den 22sten Mei I93I geopende en thans reeds een oppervlakte van 200 H.A. beslaande Zoological Park te Whipsnade in Engeland, welk dierenverblijf den toeschouwer nog meer dan het zoo juist besproken type de illusie geeft, dat de dieren ,in vrijheid" zouden leven en waarbij men eenvoudig stukken uit het landschap isoleert - stukken grasland, bosch en kreupelhout - door ze met water ${ }^{1}$ ) te omringen. Op dergelijke terreinen laat men dan een aantal tot een of meer soorten behoorende dieren loopen; in de eerste plaats begrijpelijkerwijs dieren, die ook in het wild in grootere of kleinere troepen leven, zooals verschillende soorten zebra's, runderen, antilopen, herten, kameelen, lama's, zwijnen, kangoeroe's, voorts leeuwen, tijgers, beren, enz. Bij de planteneters kan men dan verder ook nog troepen vogels onderbrengen, zooals struisvogels, flamingo's, ooievaars, reigers, ganzen, kraanvogels enz. enz.. Onder gunstige omstandigheden kunnen dergelijke groote, hier en daar met enkele boomen begroeide of met bosch omzoomde velden, met de daarop in beweging zijnde of rustende dieren, den toeschouwer prachtige en interessante tafereelen te genieten geven; in den zomer, wanneer het warm is, komt het midden op den dag echter vaak voor, dat alle dieren een rustig schaduwplekje opgezocht hebben en dat, indien de geïsoleerde terreinen, waarop de dieren leven, werkelijk groot zijn, de menschelijke bezoeker heele afstanden aflegt, zonder een enkel dier te zien te krijgen. Het door het publiek over het algemeen bijzonder gewaardeerde nauwe contact, vooral met groote dieren, komt onder dergelijke omstandigheden uit den aard der zaak veel minder gemakkelijk tot stand dan in den gewonen dierentuin.

Het bij elkaar houden van een vrij groot aantal dieren binnen een wel groote, maar tenslotte toch beperkte en afgesloten ruimte en het hen daar gemeenschappelijk voeren heeft echter nog veel meer bezwaren. Bij het gemeenschappelijk gevoederd worden en dag en nacht bijeenblijven komen de zwakkere dieren moeilijker aan hun voer dan de sterkere, die de zwakkere vaak van het voedsel verdrijven, zoodat deze laatste steeds meer achteruit gaan. Verder kan, waar door de oppassers niet elk dier geregeld apart verzorgd en waargenomen kan worden, een ziek dier niet alleen een geheele kudde, maar in som-

1) Provisorisch zijn de hier bedoelde terreinen te Whipsnade op het oogenblik op vele plaatsen nog door metaaldraadwerk van elkaar gescheiden. 
mige gevallen ook den bodem van het terrein infecteeren, voordat men bemerkt, dat een der dieren ziek is. Dit alles komt dan ook zeer duidelijk tot uitdrukking in de ziekte- en sterftecijfers der dieren, die op dergelijke terreinen gehouden worden.

Waar zooveel dieren op hetzelfde terrein bijeen zijn, komen tenslotte zoowel tusschen soortgenooten als tusschen dieren, die tot verschillende soorten behooren, vaak gevechten voor, die met den dood of met een onherstelbare verwonding of verminking van een der vechtenden eindigen, terwijl het op dergelijke terreinen, gezien ook de verdere omstandigheden, meestal niet mogelijk is in zulke gevallen tijdig tusschenbeide te komen.

Langzamerhand heeft men dit alles juist leeren inzien. Men laat dan ook tegenwoordig geen dieren meer bij elkaar, die op den duur onvermijdelijk slaags moeten raken. Voorts moeten de dieren, die overdag in troepen bijeen zijn, des nachts ondergebracht worden in individueele stallen. Dus elk dier komt dan weer afzonderlijk in zijn eigen nachtverblijf, waaraan vaak nog een klein geïsoleerd buitenperk verbonden is en waar het dier apart gevoerd kan worden, waar men het kan waarnemen, zijn mest controleeren enz.. Ook kan het dier hier geïsoleerd blijven, b.v. wanneer het ongesteld is en onder alle verdere omstandigheden, die isolatie gewenscht doen zijn. Tenslotte zijn ook bij deze wijze van onderbrengen voor vele dieren in ons klimaat des winters goede, verwarmbare binnenverblijven onmisbaar.

De ervaring heeft geleerd, dat ziekte- en sterftecijfers onder de in een dierentuin levende dieren toenemen, naarmate men van de eenvoudige, in vele opzichten gunstige, weinig gecompliceerde en voortdurend controleer- en corrigeerbare omstandigheden, waaronder een dier in een goed beheerden dierentuin kan leven, afwijkt in de richting van het veel gecompliceerder milieu, waarin het dier in het wild verkeert, met zijn oncontroleer- en oncorrigeerbare, soms zeer ongunstige omstandigheden.

Inderdaad zijn de omstandigheden, waaronder het dier in het wild leeft, vaak zeer ongunstig. Vijanden, parasieten, ziekten, voedselschaarschte, ongunstige klimaats-invloeden en nog vele andere factoren heffen een zwaren tol aan levens. De groote of zelfs zeer groote vruchtbaarheid van vele diersoorten is dan ook een conditio sine qua non voor het voortbestaan der soort, ter compensatie van de zeer groote destructie, die in de vrije natuur plaats vindt en waarbij tallooze individuen te gronde gaan, vóór zij aan de voortplanting der soort hebben kunnen deelnemen.

Bij den mensch, die niet meer ,in het wild” leeft, is de sterfte gedaald tot ver beneden het peil, waarbij de natuurlijke vruchtbaarheid nog juist groot genoeg is, om de soort in stand te houden, welk feit problemen van economischen en ethischen aard met zich gebracht heeft.

In dit verband kan ook op het in Juli 1936 geopende menschapenstation in den tuin te Hellabrunn bij München gewezen worden.

Dit Anthropoïden-station werd nl. gebouwd volgens een plan, waaraan de 
gedachte ten grondslag ligt, dat het te eenen male onjuist is te trachten in een dierentuin de natuurlijke omstandigheden, waaronder het dier in het wild leeft, na te bootsen, maar dat men, in het algemeen, de dieren, en zeer zeker dieren als menschapen, moet onderbrengen, men zou bijna zeggen zooals menschen, in van alle gemakken voorziene hygiënische woningen, met woonen slaapvertrekken en daarmede verbonden speelterreinen in de buitenlucht, of althans buitenverblijven, die op eenvoudige doch aan alle eischen van hygiëne beantwoordende en ook in alle andere opzichten geschikte wijze zijn aangelegd. Daarbij moeten dan de woon- en slaapvertrekken goed ventileerbaar en goed verwarmbaar zijn, terwijl men er liefst ook de vochtigheid der lucht moet kunnen regelen. Voorts moeten, vooral voor jonge dieren, zooals jonge menschapen, de slaapvertrekken donker gemaakt kunnen worden, om den dieren, ook in den Europeeschen zomer met zijn korte nachten, een nacht van twaalf uur te kunnen geven, terwijl aan den anderen kant althans de woonvertrekken goed kunstmatig verlicht moeten kunnen worden, om de lange winternachten voor de dieren tot twaalf uur te bekorten.

De hierboven besproken moderne dierenverblijven, waarvan het eene type o.a. in het dierenpark te Stellingen en in het Parc Zoologique du Buis de Vincennes, het andere type b.v. in het Zoological Park te Whipsnade gereali . seerd is, hebben groote of zelfs zeer groote waarde en beteekenis voor delt toeschouwer, dus als men wil in aesthetisch en instructief opzicht; voor het welzijn en het zich thuis voelen van het dier bieden zij in het gunstigste geval evenveel, vaak minder waarborgen dan het gewone verblijf in een goeden dierentuin. Niet voor den menschelijken toeschouwer, maar wel voor het dier is het in het algemeen volkomen onverschillig, of zijn verblijf docr eeil gracint dan wel door hek- of traliewerk afgesloten wordt. Zoodra het verblijf van een dier zoo groot is, dat het in alle opzichten voldoende is voor zijn physieke behoeften, brengt elke vergrooting of complicatie daarvan een grootere ongelukken-, ziekte- en sterftekans mede.

De behoefte van de meeste dieren aan vrijheid van beweging is bovendien uitermate gering. Dit feit kan men niet alleen bij in den zoölogischen tuin levende dieren, maar ook bij dieren, die in het wild leven, constateeren.

In zijn boek: „La vie des animaux sauvages de l'Afrique” (1936) merkt Dr. Emile Gromier aangaande den gewonen Afrikaanschen rhinoceros (Diceros bicornis L.) op: „Il est d'instincts routiniers, et sa tournée est presque toujours la même. Si bien que, quand il n'est pas dérangé, on peut être à peu près certain de le trouver dans un rayon déterminé. Il y dessine peu à peu de véritables sentiers, parfaitement battus, et si bien aplanis parfois, qu'on $y$ pourrait circuler à bicyclette".

Dus juist zooals sommige dieren in den dierentuin, die over een ruim buitenverblijf beschikken, doch die zich daardoorheen, practisch gesproken, uitsluitend langs bepaalde, op den duur ook uitgesleten paadjes bewegen.

Uit den aard der zaak is het veel goedkooper een bepaald terrein, van laat 
ons b.v. zeggen ongeveer 12 H.A. grootte, aan te leggen met uitsluitend ruime „Frei-Anlagen", dan met veel dichter opeen gelegen kostbare dierenverblijven, als apen-, vogel-, reptielenhuizen enz., gelijk men die bij het gewone type goeden dierentuin aantreft. Aan den anderen kant kan men natuurlijk bij het bouwen van uitsluitend „Frei-Anlagen" heel veel minder dieren onderbrengen op dezelfde oppervlakte dan bij het gewone type dierentuin het geval is.

Dit laatste is van groote beteekenis in verband met het feit, dat een goede dierentuin, een werkelijk zoölogische tuin. er steeds naar moet streven representatief te zijn, m.a.w. moet trachten van zooveel mogelijk groepen van het dierenrijk vertegenwoordigers in zijn levende verzameling te bezitten.

Overeenkomstig al het bovenstaande kan het volgende overzicht opgesteld worden der hoofdpunten, waarmede heden ten dage, ook in verband met den geest des tijds, resp. den huidigen smaak van het publiek, bij den bouw van een zoölogischen tuin rekening gehouden zou moeten worden.

$a$. Bij den bouw, de inrichting en de ligging ten opzichte der windstreken van de dierenverblijven moet in de allereerste plaats volledig rekening gehouden worden met alle eischen, waaraan moet worden voldaan, teneinde, onder alle omstandigheden, een zoo goed en rationeel mogelijke, meestal ook individueele verzorging der dieren mogelijk te maken. Daarbij moeten het dierenverblijf en de inrichting daarvan aan den aard en de behoeften der daarin te huisvesten dieren aangepast zijn.

$b$. In de tweede plaats moet het dierenverblijf, zoo mogelijk, het dier tot eenige activiteit kunnen prikkelen en voorts het publiek een zoo gunstig mogelijke gelegenheid bieden, om het levende dier en diens gedrag onder allerlei omstandigheden gade te slaan. Daarbij dient ook speciale aandacht geschonken te worden aan de gelegenheid voor beeldende kunstenaars, om het levende dier te bestudeeren en bij hun studies als model te gebruiken.

c. De zoölogische tuin moet trachten representatief te zijn en moet dus van zooveel mogelijk systematische groepen van het dierenrijk vertegenwoordigers kunnen huisvesten.

d. Zooals zulks thans reeds bij „Artis" het geval is, behoort een moderne zoölogische tuin een centraal zoölogisch instituut te zijn, dat, naast den eigenlijken dierentuin, met bijbehoorende quarantaineverblijven, ziekenhuis, operatie-zaal, sectie-zaal en laboratorium-ruimte, een zoölogisch museum en laboratoria voor morphologisch, physiologisch, psychologisch en veterinair onderzoek omvat.

e. Een moderne zoölogische tuin moet beschikken over verschillende typen dierenverblijven, die men in hoofdzaak als volgt kan classificeeren.

Ten eerste verblijven als de apen-, vogel-, reptielenhuizen en -verblijven, die men in goede zoölogische tuinen, zooals die te Londen, Berlijn en Amsterdam, aantreft en die zijn onderverdeeld in een groot aantal niet al te groote, maar voldoend ruime, meestal in een binnen- en buitenruimte gesplitste verblijven, waarin een groot aantal, tot verschillende soorten behoorende dieren 
kan worden gehuisvest. Tot dit eerste type van verblijven moeten ook stallen met bijbehoorende perken voor runderen, antilopen, herten en nog vele andere dieren gerekend worden, daar een zoölogische tuin, die representatief wil zijn, wel zelden of nimmer alle in zijn bezit zijnde vertegenwoordigers van dergelijke diervormen op terreinen als hieronder sub ten derde bedoeld zal kunnen onderbrengen.

Ten tweede verblijven, die den menschelijken toeschouwer de illusie geven van een natuurlijk landschap en waarin de dieren een iets grootere vrijheid van beweging hebben, doch die, gecamoufleerd, in verbinding staan met aan alle eischen van verzorging der dieren beantwoordende, verwarmbare binnenverblijven, waarin de dieren bij ongunstige weersomstandigheden beschutting kunnen vinden en zoo noodig individueel verzorgd kunnen worden (type Vincennes).

Het mag niet verheeld worden, dat dergelijke verblijven, die in de practijk tot nu toe meestal de gedaante van rotslandschappen hebben aangenomen, reeds heden ten dage op sommige toeschouwers den indruk maken van een ietwat naieve nabootsing eener natuurlijke omgeving, of zelfs van een soort tooneel met décors. In verband hiermede is het de vraag, of de hier bedoelde verblijven op den duur in den smaak van het publiek zullen blijven vallen.

Ten derde als het ware uit het landschap geïsoleerde, van elkaar en van de wegen, waarover het publiek zich beweegt, door al dan niet met water gevulde grachten gescheiden terreinen, met boomen, struikgewas, waterpartijen, heuveltjes e.d., waarop kudden runderen, antilopen, herten, zebra's, struisvogels, flamingo's enz. cnz. worden losgelaten. Deze terreinen moeten van eenvoudige, rustieke, overdekte schuilplaatsen, resp. in alle opzichten geschikte nachtverblijven met voederinrichtingen voorzien zijn (type Whipsnade).

In vele gevallen moeten echter voor de op dergelijke terreinen levende dieren ook nog aan alle eischen van verzorging der dieren beantwoordende winterverblijven beschikbaar zijn, die bovendien gelegenheid moeten bieden althans bepaalde dieren, telkens wanneer zulks noodig mocht zijn, geisoleerd onder te brengen en individueel te verzorgen.

Dergelijke terreinen behoeven niet steeds zeer groot te zijn; hoe groot zij zullen kunnen zijn, zal uit den aard der zaak afhangen van de totale grootte van het voor den geheelen zoölogischen tuin beschikbare terrein.

Naast deze drie typen dierenverblijven moeten ook nog verblijven aanwezig zijn voor dieren, wier huisvesting aan zeer speciale eischen moet beantwoorden. Tot dergelijke verblijven zou men ook de zee- en zoetwater-aquaria kunnen rekenen.

Tenslotte zal in de toekomst in den zoölogischen tuin ongetwijfeld ook een gebouw aanwezig zijn, waarin het publiek iets kan ervaren van het leven van allerlei lagere dieren, die tot nu toe, om verschillende redenen, nog niet in aquaria, terraria of insectaria van den zoölogischèn tuin vertegenwoordigd zijn en daarmede ook van microscopisch kleine dieren. Daarbij zal projectie, resp. 
microscopische projectie van praeparaten van levende lagere dieren een belangrijke rol moeten spelen, zoo noodig aangevuld door cinematographische projectie van films.

In verband met het doel en den aard van een zoölogischen tuin, zooals die hierboven werden aangegeven, is uit den aard der zaak het vraagstuk eener juiste en zoo intensief en doeltreffend mogelijke voorlichting van het publiek van overwegend belang.

Deze voorlichting kan geschieden door middel van aan de dierenverblijven aangebrachte goede naambordjes, zooveel mogelijk aangevuld door iets grootere bordjes, waarop wetenswaardigheden betref fende de soort of het dier in kwestie vermeld worden, van gedrukte gidsjes voor bezoekers van den tuin, van een populair week- of maandblaadje, van deskundige voorlichting bij rondleiding van gezelschappen, van cinematographische filmvertooningen met verklarende bijschriften, van voordrachten en radio-voordrachten, van couranten- en tijdschriftartikelen.

In dit verband mogen, wat „Artis" betreft, o.a. het door het Genootschap uitgegeven gidsje, de „Artis"-film van de Heeren A. F. J. Portielje en H. C. Verkruysen, de vele voordrachten, radio-voordrachten en rondleidingen van den inspecteur voor de levende have bij het Genootschap en de vele door het Genootschap ingezonden courantenartikelen genoemd worden.

Toch mag niet verheeld worden, dat op dit gebied ook door „Artis” nog meer gedaan zou kunnen worden, indien hiertoe slechts meer werkkrachten beschikbaar waren. Dat zulks niet het geval is vloeit voort uit het daartoe niet toereikend zijn der geldmiddelen van het Genootschap.

Niet alleen in dit, maar ook in vele andere opzichten oefent thans reeds sedert bijna tien jaren het tekort aan geldmiddelen een verlammenden invloed uit op het vervullen van zijn taak door het Genootschap. Zoo moesten sedert het intreden der huidige conjunctuur de, ter compensatie van den ongunstigen invloed dier conjunctuur als stimulans tot verhoogd bezoek aan den tuin zoo hoog noodige bouw van nieuwe dierenverblijven en aanschaffing van nieuwe dieren achterwege, resp. tot een minimum beperkt blijven.

Bovendien werd in de laatste jaren een gedeelte der werkkracht, althans van het hoogere, toch reeds te weinig talrijke personeel van het Genootschap in beslag genomen door tijdroovende beslommeringen van financieelen aard.

Dat "Artis" in de hier bedoelde ongunstige financieele omstandigheden verkeert, is in het minst niet een op zichzelf staand geval. Integendeel, hetzelfde geldt heden ten dage, op enkele zeer weinige, met speciale plaatselijke gunstige omstandigheden verband houdende uitzonderingen na, voor bijna alle werkelijk zoölogische tuinen, althans in Europa, en daarbij zelfs voor tuinen, die in vele opzichten onder belangrijk gunstiger omstandigheden verkeeren dan „Artis".

Onverklaarbaar is zulks niet in het minst.

De inkomsten van een zoölogischen tuin bestaan in de eerste plaats en 
vaak practisch gesproken uitsluitend uit contributies van leden (resp. jaarabonnementsgelden) en entréegelden van bezoekers. $\mathrm{Nu}$ vertoonen bij zeer vele zoölogische tuinen in geheel Europa, waarbij men het instituut van lidmaatschappen of jaarabonnementen kent, en ook bij „Artis”, de inkomsten uit contributies, resp. jaarabonnementsgelden reeds gedurende vele tientallen jaren een achteruitgang, welke achteruitgang in de allereerste plaats verband houdt met het steeds minder locaal georiënteerd zijn van het leven. Hoevele gegoeden wonen tegenwoordig niet als forensen buiten de groote-stad, waar zij hun werk hebben, en hoevele inwoners der groote stad, die vroeger lid of jaarabonné van den zoölogischen tuin waren, gaan thans niet op hun vrije dagen naar buiten?

Wat de tweede en ook in het geval van „Artis" tegenwoordig voornaamste bron van inkomsten, die uit gewone entréegelden, aangaat, hierbij vertoonde zich, na den wereldoorlog, tot aan het tot ontwikkeling komen, na 1929, der huidige ongunstige conjunctuur, bij zeer vele zoölogische tuinen een stijging en in het geval van "Artis" zelfs een sterke stijging, welke ongetwijfeld, althans gedeeltelijk, in verband staat met een toenemen en ook een op hooger peil komen der belangstelling voor den zoölogischen tuin. $\mathrm{Na} 1929$ ging echter ook deze stijging in een daling over, waarbij, zooals reeds werd gezegd, in het geval van "Artis" de middelen ontbraken om, door het, ter stimuleering van het bezoek aan den tuin, geregeld bouwen van nieuwe dierenverblijven en aanschaffen van nieuwe dieren, te trachten deze daling althans te remmen.

Hierbij moet men nog bedenken, dat, in het algemeen, heden ten dage bij een cultureele instelling de inkomsten uit het bedrijf belangrijk lager zijn dan de uitgaven. Niemand zal verwachten, dat, om een voor de hand liggend voorbeeld te noemen, het Rijks-Museum te Amsterdam zijn uitgaven zou kunnen bestrijden uit de ontvangen entréegelden. Dat zulks, zij het slechts onder een gunstige conjunctuur, bij een zoölogischen tuin wel mogelijk is, houdt zeker voor een groot gedeelte verband met het feit, dat een dergelijke instelling, ook bij vermijding van datgene, wat niet strookt met haar cultureelen aard en van alles, dat opzettelijk den sensatielust van het publiek prikkelt, toch onwillekeurig dezen sensatielust meer of minder bevredigt, althans van die, helaas nog steeds zeer talrijke bezoekers, die naar den dierentuin gaan, alleen omdat zij gaarne griezelen, door, achter beveiligend smeedwerk, dichtbij een „bloeddorstig" en "moordzuchtig" roofdier te komen, of er vermaak in scheppen, frappante gelijkenissen te ontdekken tusschen uiterlijk en gedrag van bepaalde apen en van zekere familieleden, vrienden of kennissen.

Overigens heeft juist heden ten dage het werken op den sensatielust van het publiek allerwege een zoodanigen omvang aangenomen, dat deze factor voor den zoölogischen tuin, men zou bijna geneigd zijn te zeggen gelukkig, aan beteekenis verloren heeft.

Het was van belang ook hierop even in te gaan, omdat men veelal de meening hoort verkondigen, dat de zoölogische tuin, en met name „Artis”, zou 
moeten trachten het evenwicht tusschen ontvangsten en uitgaven te herstellen, door veel meer op den sensatielust van het publiek te werken en door van den tuin, althans tot zekere hoogte, een amusementsinrichting te maken, b.v. door het organiseeren van kermissen of voorjaarsfeesten e.d..

Afgezien van de tegen een zoodanige oplossing aan te voeren ethische bezwaren, mag men veilig aannemen, dat het inslaan van een zoodanigen weg door den zoölogischen tuin binnen afzienbaren tijd zeker op den ondergang der instelling zou uitloopen.

In vele landen heeft men dan ook ingezien, dat het in stand houden van den werkelijk zoölogischen tuin een voorwerp van overheidszorg is, evenals het in stand houden van andere cultureele instellingen.

Zoo zijn in Duitschland een groot aantal zoölogische tuinen, die vroeger particuliere instellingen waren, na den wereldoorlog gemeentelijke instellingen geworden met het gevolg, dat uit de openbare geldmiddelen in belangrijke mate wordt bijgedragen in de kosten, die het op juiste wijze vervullen van hun taak door deze zoölogische tuinen medebrengt.

In Frankrijk zijn het Parc Zoologique du Bois de Vincennes en de Ménagerie van den Jardin des Plantes te Parijs rijks- (nationale) instellingen, als onderdeelen van het Muséum National d'Histoire Naturelle.

In Italië ressorteert de zoölogische tuin te Rome onder het Governatorato di Roma en is dus, wat wij zouden noemen een gemeentelijke instelling.

In de Vereenigde Staten van Noord-Amerika is men in dit opzicht nog veel verder gegaan. Enkele voorbeelden mogen dit duidelijk maken.

De groote zoölogische tuin te New York, het „New York Zoological Park”, in het Bronx Park gelegen, is een particuliere instelling, die haar uitgaven voornamelijk bestrijdt uit een gemeentelijke subsidie. Het publiek heeft er gratis toegang, behalve des Maandags en des Donderdags. Valt echter een algemeen erkende feestdag op een Maandag of Donderdag, dan is ook dien dag de toegang gratis.

Ook de „Philadelphia Zoological Garden” is een particuliere instelling, die haar uitgaven bestrijdt uit een gemeentelijke subsidie.

De zoölogische tuin te Detroit is een gemeentelijke instelling, waarvan de uitgaven bestreden worden uit de opbrengst eener speciaal daartoe geheven belasting en daarnaast ook uit giften van particulieren. Het publiek wordt er, zooals trouwens bijna overal in de Vereenigde Staten, bijna dagelijks gratis toegelaten.

Ook de zoölogische tuin te St. Louis is een gemeentelijke instelling, waarvan de uitgaven bestreden worden uit de opbrengst eener speciale belasting.

Het „Chicago Zoological Park”, op het oogenblik in vele opzichten een der belangrijkste tuinen ter wereld, wordt, in opdracht van de Gemeente Chicago, beheerd door de „Chicago Zoological Society”. Ook voor dezen tuin worden de uitgaven bestreden uit een speciaal daartoe geheven belasting, waarbij dan ook nog weer giften van particulieren komen. 
Het „National Zoological Park” te Washington (D.C.) is, zooals de naam aanduidt, een rijks- (nationale) instelling. De toegang is er steeds gratis, zelfs voor auto's, waarmede men door het park mag rijden.

Ook hier in Nederland zal in de toekomst de zoölogische tuin zijn taak alleen bij voldoenden financieelen steun van overheidswege kunnen blijven vervullen.

Alleen bij zoodanigen steun zal het voor den zoölogischen tuin mogelijk zijn een cultureele instelling te blijven, het publiek voortdurend zoo intensief en doeltreffend mogelijk voor te lichten; voor geregelde aanvulling der levende have te zorgen en de inrichting der dierenverblijven op peil te houden, niet alleen ter verzekering van een zoo rationeel mogelijke verzorging der dieren, maar ook ter tegemoetkoming aan den geest des tijds en den hiermede verband houdenden smaak van het publiek.

Hierbij is nog een punt van belang. De ervaring opgedaan in zeer vele zoölogische tuinen in Europa heeft, helaas, vrijwel zonder uitzondering geleerd, dat verlaging van den entréeprijs practisch gesproken steeds een vermindering van inkomsten medebrengt. Dit is des te bedenkelijker, waar de zoölogische tuin, overeenkomstig zijn doel, moet streven naar een zoo groot mogelijk bezoek, zij het nog niet van geheel gratis toegelaten publiek, zooals in de Vereenigde Staten, dan toch tegen een zoo laag mogelijken entréeprijs. Een ieder, die uit ervaring weet, hoe groot en intensief de belangstelling is, die ook of misschien zelfs juist bij minder gegoeden bestaat voor het levende dier en zijn verzorging, zal de beteekenis hiervan inzien.

Ook in dit opzicht zal alleen voldoende financieele steun van overheidswege uitkomst kunnen brengen. 